\title{
Reactive Nitrogen Releases And Nitrogen Footprint During The Life-Cycles of Intensive Vegetable Production Affected By Human Feces Slurry Substitution
}

Yang Bo

Agro-Environmental Protection Institute

Zhang Tao

Aerospace Environmental Engineering Co., Ltd.

\section{Zhang Man}

Institute of Soil and Water Conservation Northwest A \& F University: Institute of Soil and Water Conservation Chinese Academy of Sciences and Ministry of Water Resources

Bo Li ( $\sim$ boli@scau.edu.cn)

South China Agricultural University https://orcid.org/0000-0003-3799-2018

\section{Research Article}

Keywords: Intensive vegetable production, Human feces slurry, Reactive N releases, Net ecosystem-economic income

Posted Date: September 14th, 2021

DOI: https://doi.org/10.21203/rs.3.rs-825961/v1

License: (c) (i) This work is licensed under a Creative Commons Attribution 4.0 International License. Read Full License 


\section{Abstract}

Evaluating the sustainability of vegetable production is crucial to secure future food supply. A two-year field study of four different vegetable crops was performed to investigate the effects of inorganic fertilizer and human feces slurry at different ratios on vegetable yields, reactive gaseous nitrogen emissions (GNrEs), reactive nitrogen (Nr) footprint and net ecosystem-economic income (NEEI) by using life-cycle analysis. Four fertilization strategies were studied, including: CK (no fertilization); CF (inorganic fertilization); CHF1 (human feces slurry/inorganic fertilizer, N ratio=1:7); and CHF2 (human slurry/inorganic fertilizer, $\mathrm{N}$ ratio=1:3). Results showed that compared with $\mathrm{CF}$ treatment, both $\mathrm{CHF} 1$ and $\mathrm{CHF} 2$ treatments increased the $\mathrm{N}_{2} \mathrm{O}+\mathrm{NO}$ emissions by $11.8 \%$ and $32.4 \%$ on average, while decreased the vegetable yields by $6.7 \%$ and $7.4 \%$, respectively. Moreover, the addition of human feces slurry increased the proportions of Nr footprint by $6.6 \%$ (CHF1) and $2.9 \%$ (CHF2) in comparison with CF treatment group. However, although CHF2 treatment significantly increased the values of GNrEs and reactive gaseous nitrogen intensity (GNrl) by $8.4 \%$ and $12.5 \%$, respectively, in relation to those in CF treatment group, it still increased farmers' income by $16,404 \mathrm{CNY}^{\mathrm{h}} \mathrm{h}^{-1}$. These findings suggest that although human feces slurry incorporation could not mitigate Nr releases, the appropriate ratio of inorganic fertilizer and human feces slurry (CHF2) is able to improve net economic income (NEI) and NEEI during intensive vegetable production. Nevertheless, the relationship between combinatorial treatment of inorganic fertilizer and human feces slurry and mitigation of $\mathrm{Nr}$ release should be explored further.

\section{Introduction}

Since 2004, Chinese government has invested RMB 8.38 billion in the construction and renovation of 21.263 million rural toilets, and the coverage of sanitary toilets in rural areas has increased from 7.5\% in 1993 to 78.5\% in 2015 (NHFPC, 2016; Cheng et al. 2018). Great achievements have been made in the rural toilet renovation, but the inevitable consequence is a large amount of feces slurry with low reutilization efficiency (Koger et al. 2014). Human feces treated in septic tanks can be used as fast-release fertilizer with considerable amounts of nitrogen, phosphorus and potassium compounds, and the Government has encouraged the in situ utilization of feces resource. It is foreseeable that with the rapid development of rural toilets, the proportion of human feces slurry may be increased further.

Vegetable is the second largest crop in terms of planting area (after grain) in China (Li et al, 2019). The annual yield of Chinese vegetables was 76.9 million tons, and the sowing area reached 2.2 million ha, accounting for $13.2 \%$ of the global sown area (Wang et al, 2018 ). In the past, a relatively high economic value of growing vegetables has encouraged farmers to use fertilizers for maximizing crop yields (Li et al. 2019), which may lead to serious environmental problems (Kim et al. 2006). But now, more and more farmers have realized that the sustainable utilization of natural resources, such as human feces slurry, could decrease the use of inorganic fertilizer as well as reduce the production costs (Zhou et al. 2019).

Nowadays, it is well known that intensive vegetable production has become an important source of reactive nitrogen (Nr) releases in China, owing to the large application amounts of $\mathrm{N}$ fertilizer and frequent irrigation events (Fan et al. 2017). Approximately $20-50 \%$ of applied fertilizer- $\mathrm{N}$ is lost as $\mathrm{Nr}$, such as gaseous emissions of ammonia $\left(\mathrm{NH}_{3}\right)$, nitric oxide (NO) and nitrous oxide $\left(\mathrm{N}_{2} \mathrm{O}\right)$, and lost to water via $\mathrm{N}$ leaching and runoff $($ Xia et al., 2016 ; Wang et al., 2019). To achieve the maximum crop yield with minimal environmental damage costs (particularly regarding $\mathrm{Nr}$ releases), many researchers have proposed the adaptive strategies of inorganic fertilizer substitution (Hillier et al. 2012; Yang et al. 2015). However, different substitute resources and different incorporation ratios might potentially result in variable effects on $\mathrm{Nr}$ releases and crop productivity due to diverse fertilizer types and $\mathrm{N}$ transformation patters in agricultural systems (Zhang et al. 2012). More importantly, there are only limited data available on the effects of combination treatment of human feces slurry and inorganic fertilizers at different ratios on $\mathrm{Nr}$ losses and crop productivity during intensive vegetable production.

Evaluating the magnitude of the impact of $\mathrm{N}$ loss on agroecosystems can generate possible solutions to mitigate climate change and other environmental problems, thus helping to raise awareness in the general public and facilitating decision making with respect to environment-friendly technological development by policy makers. In recent decades, nitrogen footprint has been proposed as a potential indicator to assess how individuals, communities, organizations, or countries contribute to nitrogen pollution through their consumption, and thereby affect the environment and human health. It is widely known as the "total amount of $\mathrm{Nr}$ [reactive nitrogen, all other forms than $\mathrm{N}_{2}$ ] released to the environment as a result of $\mathrm{N}$ consumption" (Leach et al. 2012). In fact, nitrogen footprint has been identified as a critical member of the "footprint family", i.e., a more comprehensive measure of of human impact on agroecosystem (Galli et al. 2012; Leach et al. 2012).

In the present study, a two-year field experiment was performed on four different vegetable crops to quantify the amounts of $\mathrm{Nr}$, such as $\mathrm{N}_{2} \mathrm{O}$, $\mathrm{NO}$ and $\mathrm{NH}_{3}$ emissions, after treatment with mineral $\mathrm{N}$ fertilizer and human feces slurry in an intensively managed vegetable field in the North China. The aim of this research was to evaluate the impact of different portions of inorganic fertilizer and human feces slurry on average Nr footprins and net ecosystemeconomic income (NEEI) associated with the loss of $\mathrm{N}$ during intensive vegetable production. We hypothesized that the combination treatment of inorganic fertilizer and human feces slurry at different ratios could affect the proportions of Nr footprint and NEEl during intensive vegetable production.

\section{Materials And Methods 2.1 Experimental area}


The field experiment was conducted at a suburban household in Ninghe, Tianjin, China $\left(39^{\circ} 33^{\prime} \mathrm{N}, 117^{\circ} 82^{\prime} \mathrm{E}\right)$ from April 30, 2017 to May $10,2019$.

According to the Tianjin weather station, this area was dominated by subtropical monsoon climate with an average annual rainfall of $642.8 \mathrm{~mm}$ and a mean annual air temperature of $11.2^{\circ} \mathrm{C}$. The studied soil was classified as Cambosol (equivalent to Inceptisol in the USDA Soil Taxonomy), and its main compositions included total $\mathrm{N}: 1.2 \mathrm{~g} \cdot \mathrm{kg}^{-1}$, soil organic carbon (SOC): $9.7 \mathrm{~g} \cdot \mathrm{C} \cdot \mathrm{kg}^{-1}$, cation exchange capacity (CEC): $16.3 \mathrm{cmol} \cdot \mathrm{kg}-1$ and pH: 8.4 . Human feces slurry were collected from a household septic tank nearby the experiment site, after 60 days of anaerobic fermentation, the human feces slurry can basically meet the requirements of harmlessness, and the details of the human feces slurry are listed in Table 1.

Table 1

Nutrition and Harmlessness indicators of the tested human feces

\begin{tabular}{|llll|}
\hline \multirow{4}{*}{ Nutrient } & Indicator & Unit & Value \\
& $\mathrm{pH}\left(\mathrm{H}_{2} \mathrm{O}_{5: 1}\right)$ & & $7.9 \pm 1.8$ \\
\cline { 2 - 4 } & Total nitrogen & $\left(\mathrm{g} \mathrm{kg}^{-1}\right)$ & $4.9 \pm 0.3$ \\
\cline { 2 - 4 } & Ammonium content & $\left(\mathrm{g} \mathrm{kg}^{-1}\right)$ & $2.8 \pm 0.2$ \\
\cline { 2 - 4 } & Nitrate content & $\left(\mathrm{g} \mathrm{kg}^{-1}\right)$ & $1.5 \pm 0.2$ \\
\cline { 2 - 4 } & Total phosphorus & $\left(\mathrm{g} \mathrm{kg}^{-1}\right)$ & $3.2 \pm 0.3$ \\
\cline { 2 - 4 } & Total potassium & $\left(\mathrm{g} \mathrm{kg}^{-1}\right)$ & $6.6 \pm 1.1$ \\
\cline { 2 - 4 } & Total carbon & $\left(\mathrm{g} \mathrm{kg}^{-1}\right)$ & $49.5 \pm 3.8$ \\
\hline Hygiene index & Ascaris eggs mortality & $(\%)$ & 100 \\
\cline { 2 - 4 } & Schistosomiasis eggs & - & - \\
\cline { 2 - 4 } & Hookworm eggs & - & - \\
\cline { 2 - 4 } & feces coliforms & - & 0.04 \\
\hline Salmonella. & - & - \\
\hline - means not detected. & & \\
\hline
\end{tabular}

\subsection{Experimental treatments and vegetable management}

The experiment was carried out in 3 replicate plots arranged in a randomized complete block design (each plot: $3 \times 2.5 \mathrm{~m}$ ). There were four treatment groups as follows: (i) CK, no fertilization; (ii) CF, inorganic fertilization; (iii) CHF1, combination of inorganic fertilizer and human feces slurry with a $\mathrm{N}$ ratio of 7:1; and (iv) CHF2, combination of inorganic fertilizer and human feces slurry with a $\mathrm{N}$ ratio of 3:1. In addition, four different vegetable crops were successfully grown in each year, such as fennel (Foeniculum vulgare Mill.), Chinese cabbage (Brassica rapa L.), spinach (Spinacia oleracea L.) and lettuce (Lactuca sativa L.), and there was a short fallow after the harvest of each crop. The same vegetable rotation was performed in the second year, indicating that a total of eight vegetable crops were harvested during this field experiment. The fertilizer rates of urea ( $\mathrm{N}=46.4 \%)$, calcium superphosphate $\left(\mathrm{P}_{2} \mathrm{O}_{5}=60.7 \%\right)$, potassium chloride $\left(\mathrm{K}_{2} \mathrm{O}=63.1 \%\right)$ and human feces are listed in Table 2 . All the fertilizers were incorporated into the soil 3-4 days before sowing. The rates of $\mathrm{N}$ application were set according to the local vegetable cropping regimes and fertilizing practices. Meanwhile, the crops in CK group followed the field management practices as similar to those in $\mathrm{N}$-supplied treatment groups. All vegetable fields were plowed before transplanting or sowing. According to the local practices, the application of $\mathrm{N}$ fertilizer was often paired with irrigation. 
Table 2

Annual fertilizer application rates for the different experimental treatments of vegetables $\left(\mathrm{kg} \mathrm{ha}^{-1}\right)$.

\begin{tabular}{|c|c|c|c|c|c|}
\hline \multirow[t]{2}{*}{ Treatments } & \multirow[t]{2}{*}{ Application date } & \multirow[t]{2}{*}{ Vegetable rotation } & \multicolumn{3}{|c|}{$\begin{array}{l}\text { Applied fertilizers rate }\left(\mathrm{kg} \mathrm{ha}^{-1} \mathrm{yr}^{-1}\right) \\
\text { Inorganic fertilizer }^{\mathrm{a}}+\text { human feces slumy }\end{array}$} \\
\hline & & & $\mathrm{N}$ & $\mathrm{P}_{2} \mathrm{O}_{5}$ & $\mathrm{~K}_{2} \mathrm{O}$ \\
\hline CK & Sep.5, 2017; Nov.8, 2017; & Fennel - Spinach - & 0 & 0 & 0 \\
\hline CF & Mar.13, 2018; July.24, 2018; & Chinese cabbage - Lettuce & 800 & 800 & 800 \\
\hline CHF1 & Sep.26, 2018; Nov.3, 2018 & & $700+100$ & $735+65$ & $665+135$ \\
\hline CHF2 & Mar.18, 2019; July.28, 2019; & & $600+200$ & $669+131$ & $531+269$ \\
\hline \multicolumn{6}{|c|}{$\begin{array}{l}\text { a Inorganic fertilizers were Urea }\left[\mathrm{CO}\left(\mathrm{NH}_{2}\right)_{2}, \mathrm{~N}=46.4 \%\right] \text {, calcium superphosphate }\left[\mathrm{Ca}\left(\mathrm{H}_{2} \mathrm{PO} 4\right)_{2}, \mathrm{P}_{2} \mathrm{O}_{5}=60.7 \%\right] \text { and potassium chloride }\left[\mathrm{KCl}, \mathrm{K}{ }_{2} \mathrm{O}=\right. \\
63.1 \%]\end{array}$} \\
\hline
\end{tabular}

\subsection{Assessments of $\mathrm{NO}, \mathrm{N}_{2} \mathrm{O}$ and $\mathrm{NH}_{3}$ fluxes}

The $\mathrm{N}_{2} \mathrm{O}$ and $\mathrm{NO}$ fluxes in each cultivation plot were determined in situ via a static opaque chamber method (Zheng et al., 2008). Briefly, four gaseous samples were collected from the chamber headspace with polypropylene syringes (20 mL capacity) at $0,10,20$, and 30 min following chamber closure. Approximately $1 \mathrm{~L}$ of gaseous sample was pulled into an evacuated sampling bag before closing the chamber; and 30 min later (i.e., after completion of $\mathrm{N}_{2} \mathrm{O}$ sampling), another $1 \mathrm{~L}$ of gas sample was extracted into new evacuated sampling bag. The air temperature inside the chambers, soil temperature at $10 \mathrm{~cm}$ depth and soil moisture at $0-15 \mathrm{~cm}$ depth were monitored.

The concentrations of $\mathrm{N}_{2} \mathrm{O}$ were determined using an Agilent 7890A gas chromatography system (Agilent Ltd., Shanghai, China) with 2 detectors (ECD and FID). The concentrations of NO were measured by a Thermo model $42 i$ chemiluminescence NO-NO-NOx analyzer (Thermo Environmental Instruments Inc., Franklin, MA, USA). $\mathrm{NH}_{3}$ volatilization fluxes were assessed with a continuous air-flow enclosure method (Sun et al., 2017), and the measurement device consisted of a chamber, two flacks a vacuum pump and a vent pipe. The absorbent for $\mathrm{NH}_{3} \mathrm{was} 80 \mathrm{~mL}$ of $2 \% \mathrm{w} / \mathrm{v}$ boric acid, and the absorption was determined by titration with $0.01 \mathrm{M} \mathrm{H}_{2} \mathrm{SO}_{4}$ using a mixture of bromocresol green and methyl red (in ethanol solution) as an indicator. $\mathrm{NH}_{3}$ volatilization was measured once a day after fertilization until no volatilized gas was detectable (about 10 days).

The gaseous reactive nitrogen emissions (GNrEs, $\mathrm{kg} \cdot \mathrm{N} \cdot \mathrm{ha}^{-1}$ ) and the reactive gaseous $\mathrm{N}$ intensity (GNrl; $\left.\mathrm{kg} \cdot \mathrm{N} \cdot \mathrm{t}^{-1} \mathrm{yield}\right)$ was calculated using the following equations:

$\mathrm{GNrEs}=\sum_{j=1}^{n} F C_{\mathrm{N} 2 \mathrm{O}+\mathrm{NO}+\mathrm{NH} 3}$

$\mathrm{GNrl}=\mathrm{GNrEs} /$ vegetable yield(fresh yield)

\subsection{Vegetable yield, above-ground $\mathrm{N}$ uptake and use efficiency}

After reaching physiological maturity, the above-ground parts of each vegetable crop in each plot were weighted and recorded as fresh weight. Subsequently, total $\mathrm{N}$ uptake was calculated from the biomass of harvested crop within each plot. The crop biomass was air-dried, and then oven-dried at $65^{\circ} \mathrm{C}$ for 3 days. After drying, the yield of dry matter was determined. Subsamples were then ground using a ball mill, and their $\mathrm{N}$ content was evaluated by a FOSS N analyzer (KT260, Foss Co., Germany). Nitrogen use efficiency (NUE) was calculated using the following equation:

$\operatorname{NUE}(\%)=\delta \mathrm{TU}_{\mathrm{N}^{-} \mathrm{CK}} / \mathrm{TN}$

where $\mathrm{TU}_{\mathrm{N}-\mathrm{CK}}$ is the difference in the $\mathrm{N}$ content of the above-ground crops between $\mathrm{N}$-supplied treatment groups and control group (kg.ha ${ }^{-1}$ ); and $\mathrm{TN}$ is the total input of fertilizer $\mathrm{N}\left(\mathrm{kg} \cdot \mathrm{ha}^{-1}\right)$.

\subsection{Estimation of $\mathrm{Nr}$ footprint, ecosystem input and ecosystem-economic income}

The Nr footprint ( $\mathrm{g} \cdot \mathrm{N} \cdot \mathrm{kg}^{-1}$ food) was calculated as follows:

Nr footprint $=\left(\sum_{i=1}^{m} A I_{i_{N r}}+\sum_{j=1}^{n} F C_{j_{N r}}\right) /$ vegetable yield

where $\mathrm{Al}_{\mathrm{iNr}}$ indicates the loss of $\mathrm{Nr}$ (primarily through $\mathrm{NO}_{X}$ and $\mathrm{N}_{2} \mathrm{O}$ emissions) during the harvesting and postharvest handling of agricultural inputs, and the values are shown in Table $\mathrm{S} 1 ; \mathrm{FC}_{\mathrm{jNr}}$ denotes the loss of $\mathrm{Nr}$ during farm cultivation (primarily through $\mathrm{NO}_{\mathrm{X}}$ and $\mathrm{N}_{2} \mathrm{O}$ emissions, $\mathrm{N}$ leaching and 
runoff, and $\mathrm{NH}_{3}$ volatilization). The amounts of $\mathrm{N}_{2} \mathrm{O}$ and $\mathrm{NO}$ emissions were estimated in this field study by using both static chamber and gas chromatography methods, and other $\mathrm{Nr}$ species were determined by multiplying the amount of fertilizer by their individual emission factor as described by $\mathrm{Ti}$ et al. (2015), i.e., 0.14 and 0.12 for open-air and greenhouse vegetable cropping systems, respectively. The vegetable yields used in this formula were dry matter yields.

The environmental external cost is constituted of the global warming associated with greenhouse gas emissions, soil acidification linked to $\mathrm{NH}_{3}$ and $\mathrm{NO}_{x}$ emissions, and aquatic eutrophication resulted from $\mathrm{NH}_{3}$ emission as well as $\mathrm{N}$ leaching + runoff (Xia and Yan, 2012). Here, the ecosystem input (CNY ha ${ }^{-1}$ ) associated with $\mathrm{N}$ loss was assessed using the following equation:

environmental external cost $=\sum_{i=1}^{n} N r_{i} A * P i$

where $\mathrm{Nr}_{\mathrm{i}} \mathrm{A}(\mathrm{kg} \mathrm{N})$ indicates the released amount of specific $\mathrm{Nr}$ forms; and $\mathrm{Pi}\left(¥ \mathrm{~kg}^{-1} \mathrm{~N}\right)$ is the cost to climate change, ecosystems and human health per $\mathrm{kg}$ of specific $\mathrm{Nr}$ (Table S2).

Net economic income (NEl; CNY ha-1) and net ecosystem-economic income (NEEI, CNY ha-1) for crop production were determined using the following equations:

$\mathrm{NEI}=$ yield income - input cost

$\mathrm{NEEI}=\mathrm{NEI}$ - environmental external cost

where 'yield income' (CNY kg-1) represents the market value of each crop; 'input cost' (CNY kg-1) denotes the cost (per kg) incurred during food production, including procurement of labor and agricultural materials; and 'environmental external cost' $\left(\mathrm{CNY} \mathrm{kg}^{-1}\right)$ indicates the cost (per kg) incurred during food production as a consequence of damage triggered by $\mathrm{Nr}$ release.

\subsection{Statistical analysis}

Statistical analysis was carried out using JMP version 9.0 (SAS Institute Inc., Cary, NC, USA, 2010). All data were normally distributed and had homogeneous variances, hence, the experimental results were analyzed with a parametric test. The statistical comparison the annual and seasonal cumulative emissions of $\mathrm{N}_{2} \mathrm{O}$ and $\mathrm{NO}$, vegetable yield, and $\mathrm{Nr}$ footprints among different treatment groups was conducted using an one-way analysis of variance (ANOVA). Tukey's multiple range test was employed to assess whether there is any significant difference between the treatment groups at a significance level of $<0.05$.

\section{Results}

\subsection{Reactive gaseous nitrogen emissions}

During the vegetable production period, $\mathrm{N}_{2} \mathrm{O}$ and $\mathrm{NO}$ emissions peaked after the application of $\mathrm{N}$ fertilizer, tailed off after one week, and then remained low (Fig. 1a). Notably, the peaks of NO fluxes were lower than those of $\mathrm{N}_{2} \mathrm{O}$ (Fig. 1b). The seasonal $\mathrm{N}_{2} \mathrm{O}$ emissions occurred mainly in the fennel planting season, which might attributed to the relatively high temperature. The largest NO flux peak occurred in the Chinese cabbage growing season after treatment with CHF2. Despite relatively lower temperature during the planting seasons of spinach and Chinese cabbage, several NO fluxes peaks were still observed, mainly due to a decrease soil moisture that is conducive to NO emissions.

The cumulative reactive gaseous nitrogen emissions generated from different treatments are presented in Table 3. The average seasonal cumulative $\mathrm{N}_{2} \mathrm{O}, \mathrm{NO}$ and $\mathrm{NH}_{3}$ fluxes of the four treatment groups ranged from $5.9-17.1 \mathrm{~kg} \cdot \mathrm{N} \cdot \mathrm{ha}^{-1}, 1.6-5.4 \mathrm{~kg} \cdot \mathrm{N} \cdot \mathrm{ha}{ }^{-1}$ and $5.1-12.7 \mathrm{~kg} \cdot \mathrm{N} \cdot \mathrm{ha}-1$, respectively. Notably, CHF2 treatment significantly increased $\mathrm{N}_{2} \mathrm{O}$ emissions by $44.9 \%$ compared to the CF treatment groups, respectively ( $p<0.05$; Table 3 ). The lowest average cumulative NO emissions were found in CHF1 group among the three N-supplied treatment groups, but the differences were not statistically significant $(p>0.05)$. The lowest $\mathrm{NH}_{3}$ emission was recorded in $\mathrm{CHF} 2$, which was remarkably lower than that in $\mathrm{CF}(p<0.05)$. In addition, $\mathrm{CHF} 2$ treatment significantly increased GNrEs and GNrl by $8.4 \%$ and $12.5 \%$ when compared to CF treatment group $(p<0.05)$, and these values were the highest among the three $\mathrm{N}$-supplied treatment groups. 
Table 3

Mean annual $\mathrm{N}_{2} \mathrm{O}, \mathrm{NO}$ and $\mathrm{NH}_{3}$ emissions, cumulative reactive gaseous nitrogen emissions (GNrEs) and reactive gaseous nitrogen intensity (GNrl) over the two years vegetable cycles.

\begin{tabular}{|c|c|c|c|c|c|}
\hline \multirow[t]{2}{*}{ Treatments } & $\mathrm{N}_{2} \mathrm{O}$ emissions & NO emissions & $\mathrm{NH}_{3}$ emissions & GNrEs & GNrl \\
\hline & kg N ha-1 & kg Nha-1 & kg N ha-1 & $\mathrm{kg} \mathrm{N} \mathrm{ha}^{-1}$ & $\mathrm{~kg} \mathrm{~N} \mathrm{t}^{-1}$ yield \\
\hline CK & $5.9 \pm 1.5 \mathrm{c}$ & $1.6 \pm 0.2 b$ & $5.1 \pm 0.4 \mathrm{c}$ & $12.6 \pm 1.6 \mathrm{c}$ & $0.13 \pm 0.01 c$ \\
\hline CF & $11.8 \pm 1.6 b$ & $5.2 \pm 0.9 a$ & $12.7 \pm 1.3 \mathrm{a}$ & $29.7 \pm 3.5 b$ & $0.16 \pm 0.01 b$ \\
\hline $\mathrm{CFH} 1$ & $14.5 \pm 2.9 \mathrm{ab}$ & $4.5 \pm 1.0 \mathrm{a}$ & $10.4 \pm 2.8 \mathrm{ab}$ & $29.4 \pm 4.1 b$ & $0.17 \pm 0.02 a b$ \\
\hline $\mathrm{CFH} 2$ & $17.1 \pm 3.1 \mathrm{a}$ & $5.4 \pm 1.4 \mathrm{a}$ & $9.7 \pm 1.1 b$ & $32.2 \pm 3.9 \mathrm{a}$ & $0.18 \pm 0.02 a$ \\
\hline
\end{tabular}

\subsection{Vegetable yield and economic benefits}

The vegetable fresh yield and economic benefits among all the treatment groups are shown in Table 4 . Not unexpectedly, it was found that the three $\mathrm{N}$ supplied treatment groups (CF, CHF1 and CHF2) markedly elevated the yields of vegetable (91.3\%, $77.2 \%$ and $78.5 \%$, respectively) compared to CK treatment group $\left(p<0.05\right.$; Table 4). The highest average yield $\left(190.2 \mathrm{t} \cdot \mathrm{ha}^{-1} \cdot \mathrm{yr}^{-1}\right)$ of vegetable was observed in CF treatment, and as a comparison, the two combinatorial treatments with human feces and inorganic fertilizer (CHF1 and CHF2) decreased the average vegetable yields by $7.4 \%$ and $6.7 \%$, respectively. However, no significant difference in vegetable yields was noted among all the $\mathrm{N}$-supplied treatment groups.

Table 4

Mean annual vegetable yields $\left(\mathrm{t}^{-1} \mathrm{ha}^{-1}\right)$ and components of net ecosystem economic income (NEEI) (CNY ha $\left.{ }^{-1}\right)$ under different fertilizer strategies in intensive vegetable production.

\begin{tabular}{|c|c|c|c|c|c|c|c|c|c|c|c|}
\hline \multirow[t]{2}{*}{ Treatments } & \multirow[t]{2}{*}{$\begin{array}{l}\text { Yield } \\
\text { (t ha- } \\
\left.{ }^{1}\right)\end{array}$} & \multirow[t]{2}{*}{$\begin{array}{l}\text { Output } \\
(\text { CNY } \\
\left.\mathrm{ha}^{-1}\right)\end{array}$} & \multicolumn{4}{|c|}{$\begin{array}{l}\text { agricultural input } \\
\left(\mathrm{CNY} \mathrm{ha}{ }^{-1}\right)\end{array}$} & \multicolumn{2}{|c|}{$\begin{array}{l}\text { Environmental } \\
\text { external cost } \\
\left(\mathrm{CNY} \mathrm{ha}{ }^{-1}\right)\end{array}$} & \multirow{2}{*}{$\begin{array}{l}\begin{array}{l}\text { Net } \\
\text { economic- }\end{array} \\
\text { income } \\
\text { (CNY ha- } \\
\begin{array}{l}\text { 1) } \\
\text { (C) }\end{array}\end{array}$} & \multirow{2}{*}{$\begin{array}{l}\begin{array}{l}\text { Net } \\
\text { ecosystem- } \\
\text { economic } \\
\text { income }\end{array} \\
\text { (CNY ha-1) }\end{array}$} & \multirow{2}{*}{$\begin{array}{l}\text { ratio of } \\
\text { the NEI } \\
\text { and } \\
\text { NEEI } \\
(\%)\end{array}$} \\
\hline & & & seed & $\begin{array}{l}\text { chemical } \\
\text { fertilizers }\end{array}$ & labor & others & GNrEs & $\begin{array}{l}\text { Leaching } \\
\& \\
\text { running }\end{array}$ & & & \\
\hline CK & $\begin{array}{l}99.4 \\
\pm \\
10.8 \mathrm{~b}\end{array}$ & 301097 & 11835 & & & 3475 & 732 & 0 & 285787 & 285055 & 0.02 \\
\hline $\mathrm{CF}$ & $\begin{array}{l}190.2 \\
\pm 7.5 a\end{array}$ & 434520 & 11835 & 18904 & & 3475 & 1618 & 1228 & 400306 & 397460 & 0.05 \\
\hline $\mathrm{CFH} 1$ & $\begin{array}{l}176.1 \\
\pm 4.7 a\end{array}$ & 415452 & 11835 & 16418 & 800 & 3475 & 1737 & 1228 & 382924 & 379959 & 0.04 \\
\hline $\mathrm{CFH} 2$ & $\begin{array}{l}177.4 \\
\pm \\
10.8 \mathrm{a}\end{array}$ & 444980 & 11835 & 13932 & 800 & 3475 & 1955 & 1228 & 414938 & 411755 & 0.05 \\
\hline
\end{tabular}

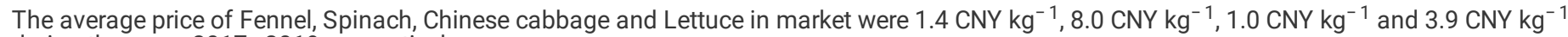
during the years 2017-2019, respectively.

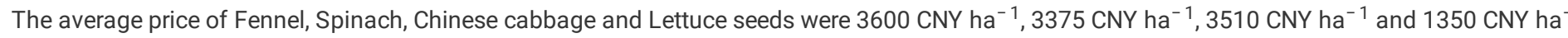
1 .

The average price of fertilizer was $4.1 \mathrm{CNY} \mathrm{kg}{ }^{-1}$ for urea, $3.4 \mathrm{CNY} \mathrm{kg}{ }^{-1}$ for calcium superphosphate and $5.8 \mathrm{CNY} \mathrm{kg}^{-1}$ for potassium chloride, respectively.

The labor means septic tank cleaning, about 200 CNY once for three months.

The others contained plastic film and pesticide.

Table 4 also shows the total economical balance for the input resources, the output profits, and the environmental cost for different treatment groups averaged over two years. The inputs for agricultural production, such as seeds (34.6-39.4\%) and fertilizer (46.4-55.3\%), constituted an important part of the total input of the N-supplied vegetable cropping system. Given that most farmers have enough family laborers to work on vegetable production, the labor cost generally included septic tank cleaning only. In addition, compared to CF treatment, $\mathrm{CFH} 2$ and CFH1 treatments increased (3.7 \%) and decreased (4.3\%) the farmer's economic income, respectively. The environmental external cost associated with the GNrE as well as the leaching and runoff caused by $\mathrm{N}$ application should be considered due to their influences on the society. The total environmental external cost varied from 732 to $3183 \mathrm{CNY} \mathrm{ha}{ }^{-1}$ in the four treatment groups, which accounted for $4.6-9.6 \%$ of the total inputs (Table 4). 


\subsection{N uptake and NUE}

Higher $\mathrm{N}$ uptake $\left(0.69 \mathrm{~kg} \cdot \mathrm{N} \cdot \mathrm{ha}^{-1}\right)$ was observed in $\mathrm{CF}$ treatment group, whereas the addition of human feces could decrease $\mathrm{N}$ uptake compared to $\mathrm{CF}$ treatment group, but the differences were not statistically significant ( $p>0.05$; Fig. 2a). Taking the amounts of $\mathrm{N}$ uptake into considerations, we also quantified the NUE in this study (Fig. 2b). The NUE of all the four vegetable crops ranged from $16.8-20.3 \%$ among all the N-supplied treatment groups. In agreement with the results of vegetable yields, CHF1 and CHF2 treatments both decreased the NUE values by $17.2 \%$ and $5.4 \%$, respectively, when compared to CF treatment group, but statistical significance was only found in CHF1 treatment group $(p<0.05)$.

\section{$3.4 \mathrm{Nr}$ losses and $\mathrm{Nr}$ footprint}

The estimated total losses of $\mathrm{Nr}$ for all the $\mathrm{N}$-supplied treatments varied from 177.6 to $184.1 \mathrm{~kg} \cdot \mathrm{N} \cdot \mathrm{ha}^{-1}$, accounting for $22.2-23.1 \%$ of $\mathrm{N}$ application rates. The loss of $\mathrm{Nr}$ was mainly dominated by $\mathrm{N}$ leaching and runoff, with the combined proportions ranging from $71.7 \%$ to $74.3 \%$. The other (secondary) contributing factors included fertilizers, pesticide and plastic film. $\mathrm{N}$ application in all the N-supplied treatment groups significantly increased the losses of $\mathrm{Nr}$ when compared to $\mathrm{CK}$ group. In comparison with $\mathrm{CF}$ treatment group, the human feces substitution treatments slightly ( $p>$ 0.05 ) reduced the losses of $\mathrm{Nr}$ by approximately $2.3 \%$ in CHF1 and $3.6 \%$ in CHF2.

The $\mathrm{Nr}$ footprint of vegetable production varied from 1.7 (CK) to $11.7 \mathrm{~g} \cdot \mathrm{N} \cdot \mathrm{kg}^{-1}$ (CHF1). Compared to $\mathrm{CK}$ treatment, $\mathrm{N}$ application remarkably increased the value of $\mathrm{Nr}$ footprint ( $p<0.05$; Fig. 3). In addition, a consistent effect of the combination of inorganic fertilizer and human feces slurry at different ratios was detected in both $\mathrm{CHF} 1$ and $\mathrm{CHF} 2$ treatment groups. Compared to CF treatment, the proportions of Nr footprint were increased by $4.4 \%$ in CHF1 group and decreased by $0.5 \%$ in CHF2 group $(p>0.05)$.

\section{Discussion}

\subsection{Effects of different fertilization strategies on GNrEs}

The $\mathrm{N}$ fertilizer used in the field could increase the initial levels of $\mathrm{NH}_{4}{ }^{+}$and $\mathrm{NO}_{3}{ }^{-}$during nitrification and denitrification processes (Cardoso et al. 2017), which in turn regulates the $\mathrm{N}_{2} \mathrm{O}$ emissions (Liu et al. 2012). In our experiment, $\mathrm{CHF} 2$ treatment exhibited significantly higher cumulative $\mathrm{N}_{2} \mathrm{O}$ emissions than CF treatment, which probably due to higher moisture content in the former (since the water content of human feces slurry as high as $95 \%$ ). This suggests that an increase in soil moisture content may serve as a key driver of $\mathrm{N}_{2} \mathrm{O}$ emissions (Uchida et al. 2011; Hu et al. 2017; Feng et al. 2018), and such phenomenon has been observed in previous researches (Pezzolla et al. 2012; Cardenas et al. 2016), particularly when the soil water-filled pores exceeded $60 \%$. Besides, $\mathrm{NH}_{4}{ }^{+}$nitrification has been recognized as an important pathway for $\mathrm{N}_{2} \mathrm{O}$ emissions in $\mathrm{N}$ fertilizer-amended soils (Skiba et al., 1993). Indeed, the human feces slurry used in this study contained large amounts of ammoniacal nitrogen, which can provide a considerable amount of nitrification substrate. However, urea needs to be mineralized to $\mathrm{HCO}_{3}{ }^{-}$and $\mathrm{NH}_{4}{ }^{+}$in soils before denitrification can take place. This may explain why the increase in $\mathrm{N}_{2} \mathrm{O}$ losses induced by human feces slurry application may occur more rapidly than that observed for urea fertilizers.

$\mathrm{N}$ fertilization is one of the key points of NO emissions (Sanchez et al. 2010). Our results showed that the types of fertilizer used exhibited no remarkable effect on NO emissions. Liu et al (2016) presumed that ammonium nitrate was the most effective for increasing soil NO emissions among different types of inorganic $\mathrm{N}$ fertilizers. However, those findings did not provide information about the pathway of NO production. In recent years, numerous investigations have regarded nitrification as the most predominant process for producing NO (Fan et al. 2020). In the present study, NO emission was the lowest among the three gaseous forms of Nr. NO emission could occur in upland crop systems, but was undetectable in anaerobic soils, which might be attributed to the slow diffusion or fast reduction of NO (Russow et al. 2009; Liu et al. 2016).

$\mathrm{NH}_{3}$ emission is primarily influenced by various abiotic factors, including $\mathrm{NH}_{4}{ }^{+}$concentration, $\mathrm{pH}$ and soil texture (Tasistro et al. 2007; Schraml et al. 2016). In our study, treatment with a relatively high proportion of human feces (CHF2) demonstrated a significantly lower $\mathrm{NH}_{3}$ loss than $\mathrm{CF}_{\text {, probably }}$ due to (i) higher $\mathrm{pH}$ of human feces slurry and (ii) increased infiltration of liquid slurry into soil. Sha and co-workers (2020) have suggested that a deep placement of fertilizers (e.g., ammonium-based fertilizer, liquid manure, etc.) can decrease $\mathrm{NH}_{3}$ emissions in alkaline soils at high air temperature. An interesting point in the study presented here was that the amounts of $\mathrm{N}_{2} \mathrm{O}+\mathrm{NO}$ emissions in the three $\mathrm{N}$-supplied treatment groups decreased in the following order: CHF2 $\rightarrow$ CHF1 $\rightarrow$ CF, whereas the trend of $\mathrm{NH}_{3}$ emissions was reversed as follows: CF $\rightarrow$ CHF1 $\rightarrow$ CHF2. Similarly, Fan et al. (2017b) found a significant positive relationship between decreased $\mathrm{N}_{2} \mathrm{O}+\mathrm{NO}$ emissions and increased $\mathrm{NH}_{3}$ emissions in an incubation experiment of vegetable soils, given the constant amount of the substrates.

Generally, greenhouse gas intensity and global warming potential (GWP) are used to integrate the effects of greenhouse gases. In our research, GNrEs and GNrl were employed to investigate the overall impact of gaseous reactive nitrogen on the environment. Table 3 showed that $\mathrm{N}_{2} \mathrm{O}$ and $\mathrm{NH}_{3}$ were the two dominant components of GNrEs, accounting for 39.7-53.1\% and 30.1-42.8\%, respectively. These ratios are in accordance with Chen et al. (2020) who reported on one-year winter wheat/summer maize rotation system in the Northern Central Region of China. In addition, the high amounts of human feces slurry significantly increased the values of GNrEs and GNrl, indicating that the use of human feces neither decreases the emission of gaseous reactive nitrogen nor increases the yields of vegetables. This poses a substantial obstacle to the future application of human feces slurry.

4.2 Effects of human feces replacing part of nitrogen fertilizer on NUE, vegetable growth and net ecosystem economic benefits

Page $7 / 13$ 
We estimated the NUE in all the N-supplied treatments, and found that the NUE ranged from 16.8-20.3 \%, which were higher than the values reported by $\mathrm{Li}$ et al (2017). However, the two treatments incorporating human feces slurry decreased the NUE in relation to CF treatment (Fig. 2), indicating that replacing the inorganic fertilizer with human feces slurry could not effectively increase the NUE during intensive vegetable production. This could be attributed to the higher Nr emissions in CHF1 and CHF2 groups than those in CF group. Generally, substituting compound fertilizers (usually by organic matter) markedly elevated plant $\mathrm{N}$ uptake and reduced gaseous $\mathrm{N}$ losses (Zhou et al. 2016; Zhuang et al. 2019), however, the composition of human feces slurry was different from that of standard organic fertilizer, despite containing a certain amount of organic matter, and human feces usually considering as quick-acting fertilizer rather than organic fertilizer.

In this study, human feces replacing part of nitrogen fertilizer exerted no pronounced effects on the vegetable yield in two years (four successive vegetable seasons), possibly due to the fact that the total $\mathrm{N}$ application rates were relatively similar in the three $\mathrm{N}$-supplied treatment groups (Table 4). It has been shown that with $\mathrm{NH}_{4}{ }^{+}$as the dominant nitrogen form, both grain yields and $\mathrm{N}$ uptake improved than the conventional fertilizer strategy (Deppe et al. 2016). However, in this study, the vegetable yields were similar between CHF1 and CHF2 treatment groups, but did not differed greatly from CF treatment group. This was probably due to the fact that we applied human feces slurry as base fertilizer before planting/seeding, suggesting that the high $\mathrm{NH}_{4}{ }^{+}$concentration immediately upon application could not induce toxicity (cf. Müller et al., 2006). Indeed, the results of crop yields were in good agreement with the enhanced uptake of nutrients during the growing season (Cardenas et al. 2016).

Emissions of $\mathrm{NO}_{x}, \mathrm{~N}_{2} \mathrm{O}$ and $\mathrm{NH}_{3}$ can threaten human health and cause severe diseases (e.g., cataract, skin cancer, etc.), mainly via particle pollution, ground-level ozone pollution, and stratospheric ozone depletion. In China, the total health damage cost related to atmospheric Nr emissions was estimated at US\$19 - 62 billion in 2008, which is much larger than the damage costs in the United States and Europe. According to Gu et al. (2012), agricultural $\mathrm{Nr}$ emission is one of the largest sources of health-related damage, accounting for about $50 \%$ of total expenditures in China, which are consistent with the results of this study (Fig. 3). However, other reports identified $\mathrm{NO}_{\mathrm{x}}$ emissions as the largest source of health-related damage in the United States and Europe (Birch et al. 2015), which is contrary to our findings (Fig. 3), possibly because of the high $\mathrm{N}$ inputs during intensive vegetable production (Table 2). Moreover, leaching + runoff was an important contribution to the ecosystem $\mathrm{N}$ input in this study, which emphasized the importance of reducing leaching + runoff during intensive vegetable production. In addition, we used the coefficient estimated by Ti et al (2015) related to the total $\mathrm{N}$ applied, which might have underestimated the leaching + runoff losses in the two treatment groups with human feces slurry due to its rapid infiltration.

Profitability is often regarded as the main driver for farmers to improve their agricultural practices. Taking the yield income, input costs and environmental cost into consideration, we also quantified the net ecosystem economic benefits among the three $\mathrm{N}$-supplied treatment groups (Table 4). Notably, CHF2 had the highest values of NEI and NEEl, representing a sufficient incentive for farmers to alter their $\mathrm{N}$ management strategies, if such information were available for them.

\section{3 $\mathrm{Nr}$ footprint in crop production}

The evaluation of $\mathrm{Nr}$ footprint can aid better detection of the 'authentic' environmental hotspots of Nr releases in the national food system (Cheng et al. 2014; Chen et al. 2020). In our research, the $\mathrm{Nr}$ footprint ranged from $1.6-11.8 \mathrm{~g} \cdot \mathrm{N} \cdot \mathrm{kg}^{-1}$ (Fig. 3), which were comparable to the findings in a wheatmaize system in North China Plain (Xu et al. 2020) and different fertilization strategies in vegetable crop rotations in Southeast China (Zhou et al. 2019). In addition, our results indicated that the $\mathrm{N}$ leaching and runoff, with a high $\mathrm{N}$ application rate, was the dominant contribution to the field $\mathrm{Nr}$ footprint, accounting for about $72 \%$ of the total $\mathrm{Nr}$ footprint. It is commonly known that $\mathrm{N}$ fertilizer is an essential source of $\mathrm{Nr}$ emissions during crop cultivation (Chen et al., 2014). However, this is inconsistent with Xue and co-workers (2016), who analyzed the Nr footprint of double rice production in Southern China by using the life cycle assessment method, and identified that $\mathrm{NH}_{3}$ emission from paddy fields could be the main contributor. Typically, the $\mathrm{Nr}$ footprint in paddy fields is dominated by $\mathrm{NH}_{3}$ volatilization, whereas $\mathrm{N}$ leaching/runoff is a primary contributor to $\mathrm{Nr}$ footprint in the upland ecosystems (Xia et al. 2016). It is worth noting that the amount of $\mathrm{N}$ leaching and runoff in our study was estimated by the coefficient obtained from Xia et al. (2017), thereby avoiding possible uncertainty. The three $\mathrm{N}$-supplied treatment groups had the similar $\mathrm{Nr}$ footprint values $(p>0.05)$, indicating that all the fertilizer types exert a similar environmental impact.

\section{Conclusion}

A major obstacle for solving $\mathrm{N}$-driven environmental issues is the lack of knowledge on complete $\mathrm{N}$ budgets, such as the major $\mathrm{N}$ fluxes, in agricultural systems, especially those under alternative farm management practices. Our results indicate that the release of $\mathrm{Nr}$ is dominated by $\mathrm{N}$ leaching and runoff. The human feces slurry substituting for a portion of inorganic fertilizer elevated $\mathrm{Nr}$ footprint and environmental cost when compared to $\mathrm{CF}$ treatment. However, although with increasing environmental costs, CHF2 treatment increased farmers' net economic income compared to CF treatment. Our study suggests that the application of human feces slurry together with inorganic fertilizer at an appropriate ratio could increase farmers' net income, even though releases more $\mathrm{Nr}$ into environment. Therefore, further investigations are required to ensure $\mathrm{Nr}$ mitigation in cases of human feces slurry treatment during intensive vegetable production.

\section{Declarations}

\section{Acknowledgements}


We would like to thank the Yingtan Comprehensive inspection and Testing Center for providing the necessary experimental instruments.

\section{Authors Contributions}

Bo Yang: Data curation, Writing- Original draft preparation.

Tao Zhang: Conceptualization, Methodology, Software.

Man Zhang: Visualization, Investigation.

Bo Li: Supervision, Writing- Reviewing and Editing.

\section{Funding}

This work was supported by the Natural Science Foundation of Tianjin, China (Grant No.19JCQNJC13400), the Fundamental Research Funds for the Central Government (Grant No. 2020-jbkyywf-yb) and National Natural Science Foundation of China $(41601321,41807021)$

\section{Availability of data and materials}

The datasets used and/or analyzed during the current study are available from the corresponding author on reasonable request.

\section{Ethics approval and consent to participate}

Not applicable

\section{Consent for publication}

Not applicable

\section{Competing interests}

The authors declare no competing financial interests.

\section{References}

1. Birch M, Gramig B, Moomaw W, Rd D, Reeling C (2015) Why metrics matter: evaluating policy choices for reactive nitrogen in the Chesapeake bay watershed. Environ Sci Technol 45(1):168-174

2. Cardenas LM, Misselbrook TM, Hodgson C, Donovan N, Gilhespy S, Smith KA et al (2016) Effect of the application of cattle urine with or without the nitrification inhibitor DCD, and dung on greenhouse gas emissions from a UK grassland soil. Agr Ecosyst Environ 235:229-241

3. Cardoso ADS, Quintana BG, Janusckiewicz ER, Brito LDF, Morgado EDS, Reis RA et al (2017) $\mathrm{N}_{2} \mathrm{O}$ emissions from urine-treated tropical soil: effects of soil moisture and compaction, urine composition, and dung addition. Catena 157:325-332

4. Chen Z, Xu C, Ji L, Feng J, Li F, Zhou X, Fang F (2020) Effects of multi-cropping system on temporal and spatial distribution of carbon and nitrogen footprint of major crops in China. Glob. Ecol. Conserv. e00895

5. Cheng K, Yan M, Nayak D, Pan G, Smith P, Zheng J, Zheng J (2014) Carbon footprint of crop production in China: an analysis of National Statistics data. J Agr Sci 153:422-431

6. Cheng S, Li Z, Uddin SMN, Mang HP, Zhou X, Zhang J et al (2018) Toilet revolution in China. J Environ Manage 216:347-356

7. Deng J, Zhou Z, Zheng X, Liu C, Yao Z et al (2012) Annual emissions of nitrous oxide and nitric oxide from rice-wheat rotation and vegetable fields: a case study in the Tai-lake region, China. Plant Soil 360(1-2):37-53

8. Deppe M, Well R, Kücke M, Fuß R, Giesemann A, Flessa H (2016) Impact of CULTAN fertilization with ammonium sulfate on field emissions of nitrous oxide. Agr Ecosyst Environ 219:138-151

9. Fan C, Duan P, Zhang X, Shen H, Chen M, Xiong Z (2020) Mechanisms underlying the mitigation of both $\mathrm{N}_{2} \mathrm{O}$ and NO emissions with field-aged biochar in an Anthrosol. Geoderma 364:114178

10. Fan C, Li B, Xiong Z (2017) Nitrification inhibitors mitigated reactive gaseous nitrogen intensity in intensive vegetable soils from China. Sci Total Environ 612:480-489

11. Feng Z, Sheng Y, Cai F, Wang W, Zhu L (2018) Separated pathways for biochar to affect soil $\mathrm{N}_{2} \mathrm{O}$ emission under different moisture contents. Sci Total Environ 645:887-894

12. Galli A, Wiedmann T, Ercin E, Knoblauch D, Ewing B, Giljum S (2012) Integrating Ecological, Carbon and Water footprint into a "Footprint Family" of indicators: Definition and role in tracking human pressure on the planet. Ecol Indic 16:100-112

13. Gu B, Ge Y, Ren Y, Xu B, Luo W, Jiang H et al (2012) Atmospheric reactive nitrogen in China: sources, recent trends, and damage costs. Environ Sci Technol 46(17):9420-9427 
14. Hillier J, Brentrup F, Wattenbach M, Walter C, Garcia-Suarez T, Mila-I-Canals L, Smith P (2012) Which cropland greenhouse gas mitigation options give the greatest benefits in different world regions? climate and soil-specific predictions from integrated empirical models. Global Change Biol 18(6):1880-1894

15. Hu HW, Trivedi P, He JZ, Singh BK (2017) Microbial nitrous oxide emissions in dryland ecosystems: mechanisms, microbiome and mitigation. Environ Microbiol 19(12):4808-4828

16. Kim JS, Oh SY, Oh KY (2006) Nutrient runoff from a Korean rice paddy watershed during multiple storm events in the growing season. J Hydrol 327(1-2):128-139

17. Koger JB, O’Brien BK, Burnette RP, Kai P, van Kempen MHJG, van Heugten E, van Kempen TATG (2014) Manure belts for harvesting urine and feces separately and improving air quality in swine facilities. Livest Sci 162:214-222

18. Leach AM, Galloway JN, Bleeker A, Erisman JW, Kohn R, Kitzes J (2012) A nitrogen footprint model to help consumers understand their role in nitrogen losses to the environment. Environ Dev 1(1):40-66

19. Li B, Bi Z, Xiong Z (2017) Dynamic responses of nitrous oxide emission and nitrogen use efficiency to nitrogen and biochar amendment in an intensified vegetable field in Southeastern China. GCB Bioenergy 9(2):400-413

20. Li J, Wan X, Liu X, Chen Y, Slaughter LC, Weindorf DC, Dong Y (2019) Changes in soil physical and chemical characteristics in intensively cultivated greenhouse vegetable fields in North China. Soil Till Res 195:104366

21. Li J, Wan X, Liu X, Chen Y, Slaughter LC, Weindorf DC, Dong Y (2019) Changes in soil physical and chemical characteristics in intensively cultivated greenhouse vegetable fields in North China. Soil Till Res 195:104366

22. Liu C, Wang K, Meng S, Zheng X, Zhou Z, Han S et al (2011) Effects of irrigation, fertilization and crop straw management on nitrous oxide and nitric oxide emissions from a wheat-maize rotation field in northern China. Agr Ecosyst Environ 140(1-2):226-233

23. Liu S, Lin F, Wu S, Ji C, Sun Y, Jin Y et al (2016) A meta-analysis of fertilizer-induced soil $\mathrm{NO}$ and combined $\mathrm{NO}+\mathrm{N}_{2} \mathrm{O}$ emissions. Global Change Biol 23(6):2520-2532

24. Müller T, Walter B, Wirtz A, Burkovski A (2006) Ammonium Toxicity in Bacteria. Curr Microbiol 52(5):400-406

25. NHFPC (2016) China Health and Family Planning Statistical Yearbook. Peking Union Medical College Press, Beijing (in Chinese)

26. Pezzolla D, Bol R, Gigliotti G, Sawamoto T, Aranzazu LL, Cardenas L et al (2012) Greenhouse gas (GHG) emissions from soils amended with digestate derived from anaerobic treatment of food waste. Rapid Commun Mass Sp 26(20):2422-2430

27. Russow R, Stange CF, Neue HU (2009) Role of nitrite and nitric oxide in the processes of nitrification and denitrification in soil: results from ${ }^{15} \mathrm{~N}$ tracer experiments. Soil Biol Biochem 41(4):785-795

28. Schraml M, Gutser R, Maier H, Schmidhalter U (2016) Ammonia loss from urea in grassland and its mitigation by the new urease inhibitor 2-NPT. J Agr Sci 154(08):1453-1462

29. Sha Z, Ma X, Loick N, Lv T, Cardenas LM, Ma Y et al (2020) Nitrogen stabilizers mitigate reactive N and greenhouse gas emissions from an arable soil in North China Plain: Field and laboratory investigation. J Clean Prod 258:121025

30. Sun H, Lu H, Chu L, Shao H, Shi W (2017) Biochar applied with appropriate rates can reduce N leaching, keep $\mathrm{N}$ retention and not increase $\mathrm{NH}_{3}$ volatilization in a coastal saline soil. Sci Total Environ 575:820-825

31. Tasistro AS, Cabrera ML, Kissel DE, Ritz CW (2007) Study on the reduction of NH3 volatilization from broiler litter through the promotion of nitrification. J Environ Sci Heal A 42(5):549-556

32. Ti C, Luo Y, Yan X (2015) Characteristics of nitrogen balance in open-air and greenhouse vegetable cropping systems of China. Environ Sci Pollut Resear 22(23):18508-18518

33. Uchida Y, Clough TJ, Kelliher FM, Hunt JE, Sherlock RR (2011) Effects of bovine urine, plants and temperature on $\mathrm{N}_{2} \mathrm{O}$ and $\mathrm{CO}_{2}$ emissions from a sub-tropical soil. Plant Soil 345(1-2):171-186

34. Van Grinsven H, Holland M, Jacobsen B, Klimont Z, Sutton M, Willems J, W (2013) Costs and benefits of nitrogen for Europe and implications for mitigation. Environ Sci Technol 47:3571-3579

35. Wang D, Guo L, Zheng L, Zhang Y, Yang R, Li M et al (2019) Effects of nitrogen fertilizer and water management practices on nitrogen leaching from a typical open field used for vegetable planting in northern China. Agr Water Manage 213:913-921

36. Wang J, Fu Z, Zhang B, Yang F, Zhang L, Shi B (2018) Decomposition of influencing factors and its spatial-temporal characteristics of vegetable production: A case study of China. Inform Process Agr 5(4):477-489

37. Xia L, Lam SK, Yan X, Chen D (2017) How Does Recycling of Livestock Manure in Agroecosystems Affect Crop Productivity, Reactive Nitrogen Losses, and Soil Carbon Balance? Environ Sci Technol 51(13):7450-7457

38. Xia L, Xia Y, Ma S, Wang J, Wang S, Zhou W, Yan X (2016) Greenhouse gas emissions and reactive nitrogen releases from rice production with simultaneous incorporation of wheat straw and nitrogen fertilizer. Biogeosciences 13:4569-4579

39. Xia Y, Yan X (2011) Life-cycle evaluation of nitrogen-use in rice-farming systems: implications for economically-optimal nitrogen rates. Biogeosciences 8:3159-3168

40. Xu Q, Hu K, Liang H, Leghari SJ, Knudsen MT (2020) Incorporating the WHCNS model to assess water and nitrogen footprint of alternative cropping systems for grain production in the North China Plain. J. Clean. Prod. 121548

Page $10 / 13$ 
41. Xue JF, Pu C, Liu SL, Zhao X, Zhang R, Chen F et al (2016) Carbon and nitrogen footprint of double rice production in southern China. Ecol indic 64:249-257

42. Yang B, Xiong Z, Wang J, Xu X, Huang Q, Shen Q (2015) Mitigating net global warming potential and greenhouse gas intensities by substituting chemical nitrogen fertilizers with organic fertilization strategies in rice-wheat annual rotation systems in China: a 3-year field experiment. Ecol Eng 81:289-297

43. Zhang J, Zhu T, Cai Z, Qin S, Muller C (2012) Effects of long-term repeated mineral and organic fertilizer applications on soil nitrogen transformations. Eur J Soil Sci 63(1):75-85

44. Zhang W, Dou Z, He P (2013) New technologies reduce greenhouse gas emissions from nitrogenous fertilizer in China. Proc. National. Acad. Sci. USA. $110,8375-8380$

45. Zheng X, Mei B, Wang Y, Xie B, Wang Y, Dong H et al (2008) Quantification of $\mathrm{N}_{2} \mathrm{O}$ fluxes from soil-plant systems may be biased by the applied gas chromatograph methodology. Plant Soil 311:211-234

46. Zhou P, Sheng H, Li Y, Tong C, Ge T, Wu J (2016) Lower C sequestration and N use efficiency by straw incorporation than manure amendment on paddy soils. Agr Ecosyst Environ 219:93-100

47. Zhou X, Lu Y, Liao Y, Zhu Q, Cheng H, Nie X et al (2019) Substitution of chemical fertilizer by Chinese milk vetch improves the sustainability of yield and accumulation of soil organic carbon in a double-rice cropping system. J Integr Agr 18(10):2381-2392

48. Zhuang M, Lam SK, Zhang J, Li H, Shan N, Yuan Y, Wang L (2019) Effect of full substituting compound fertilizer with different organic manure on reactive nitrogen losses and crop productivity in intensive vegetable production system of China. J Environ Manage 243:381-384

\section{Figures}
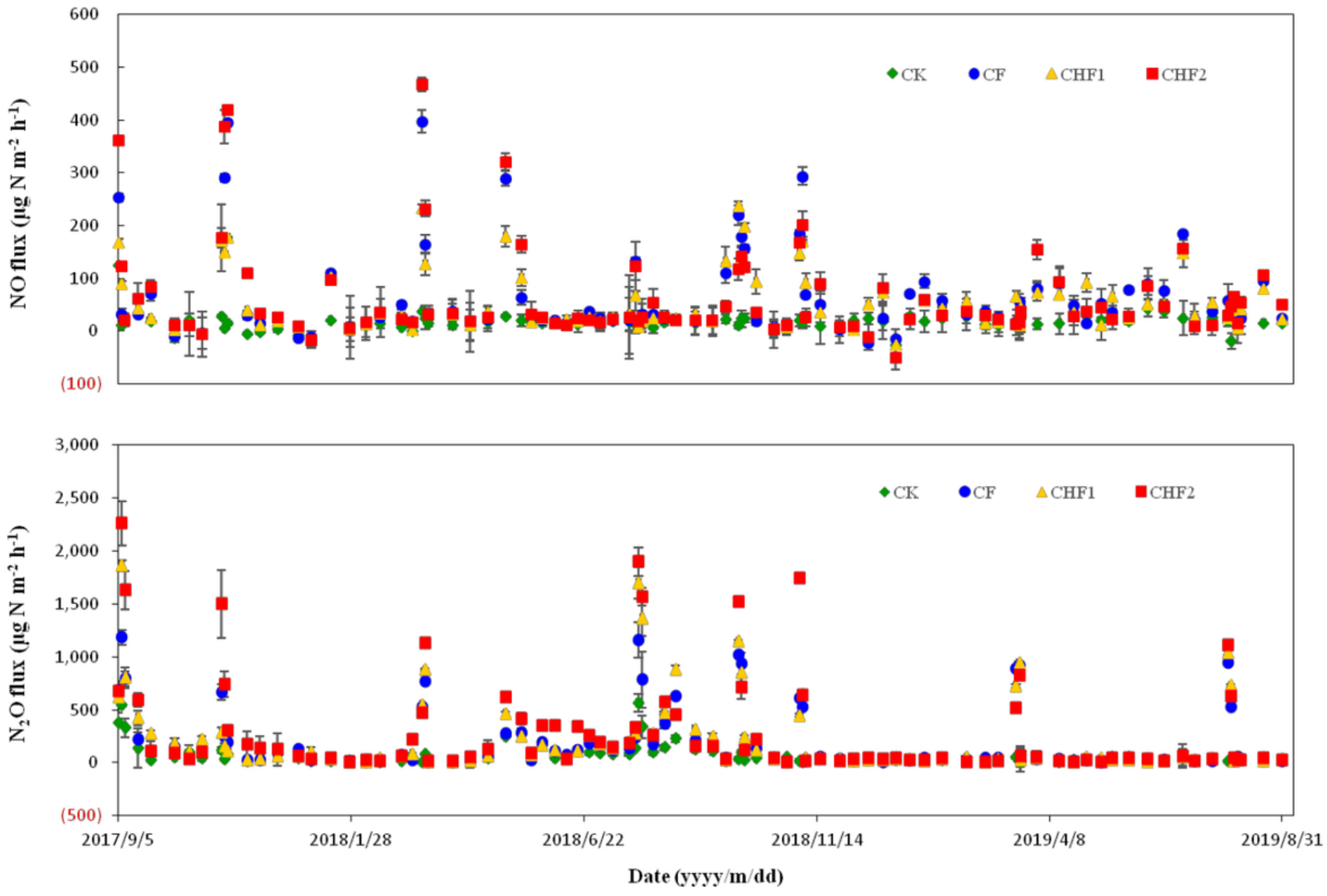

Figure 1

Dynamics of soil NO fluxes (a) and N2O (b) fluxes under different treatments in intensified vegetable field. CK, no fertilization addition; CF, inorganic fertilization addition; $\mathrm{CHF1}$, human feces slurry/inorganic fertilizer=1:7; CHF2, human feces slurry /inorganic fertilizer=1:3. The bars indicate the standard error of the mean (+SE) for the three replicates of each treatment. 

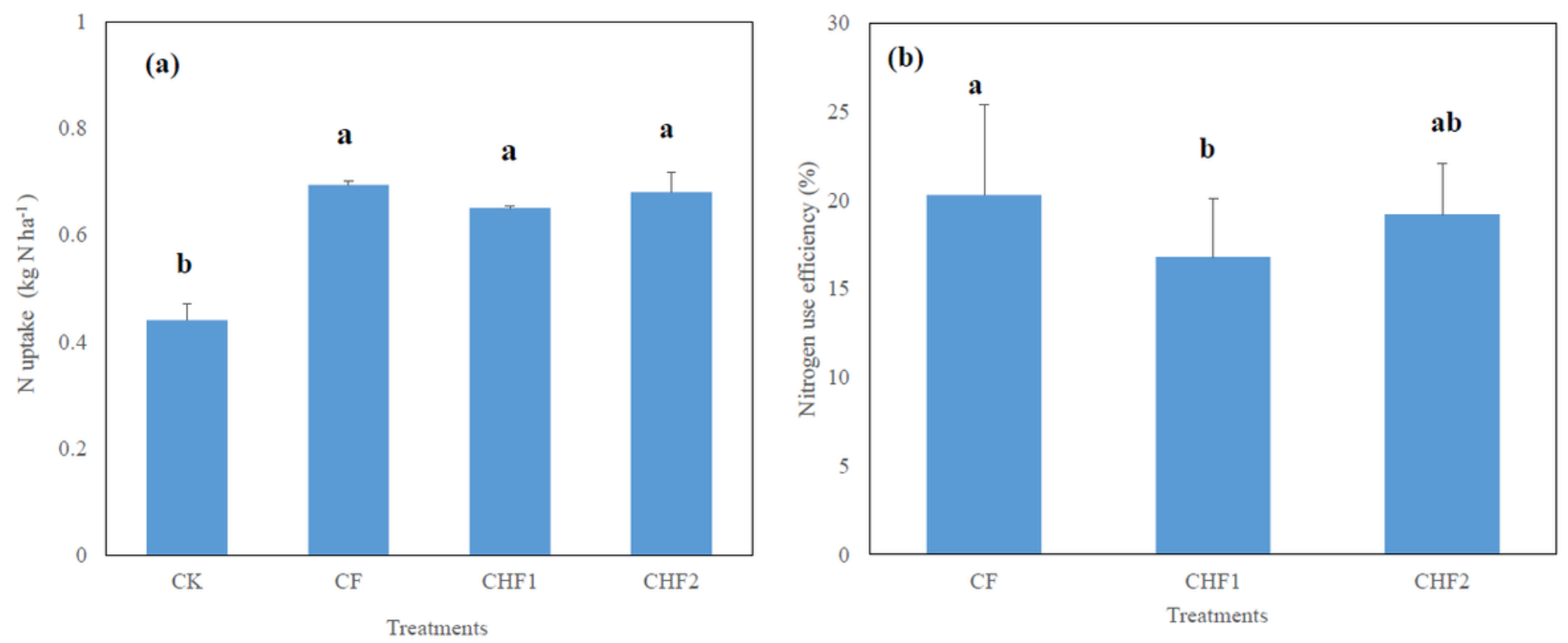

Figure 2

$\mathrm{N}$ uptake (a) and nitrogen use efficiency (b) under different treatments in intensified vegetable field. The bars indicate the standard error of the mean $(+S E)$ for the three replicates of each treatment. See Table 1 for treatment codes.

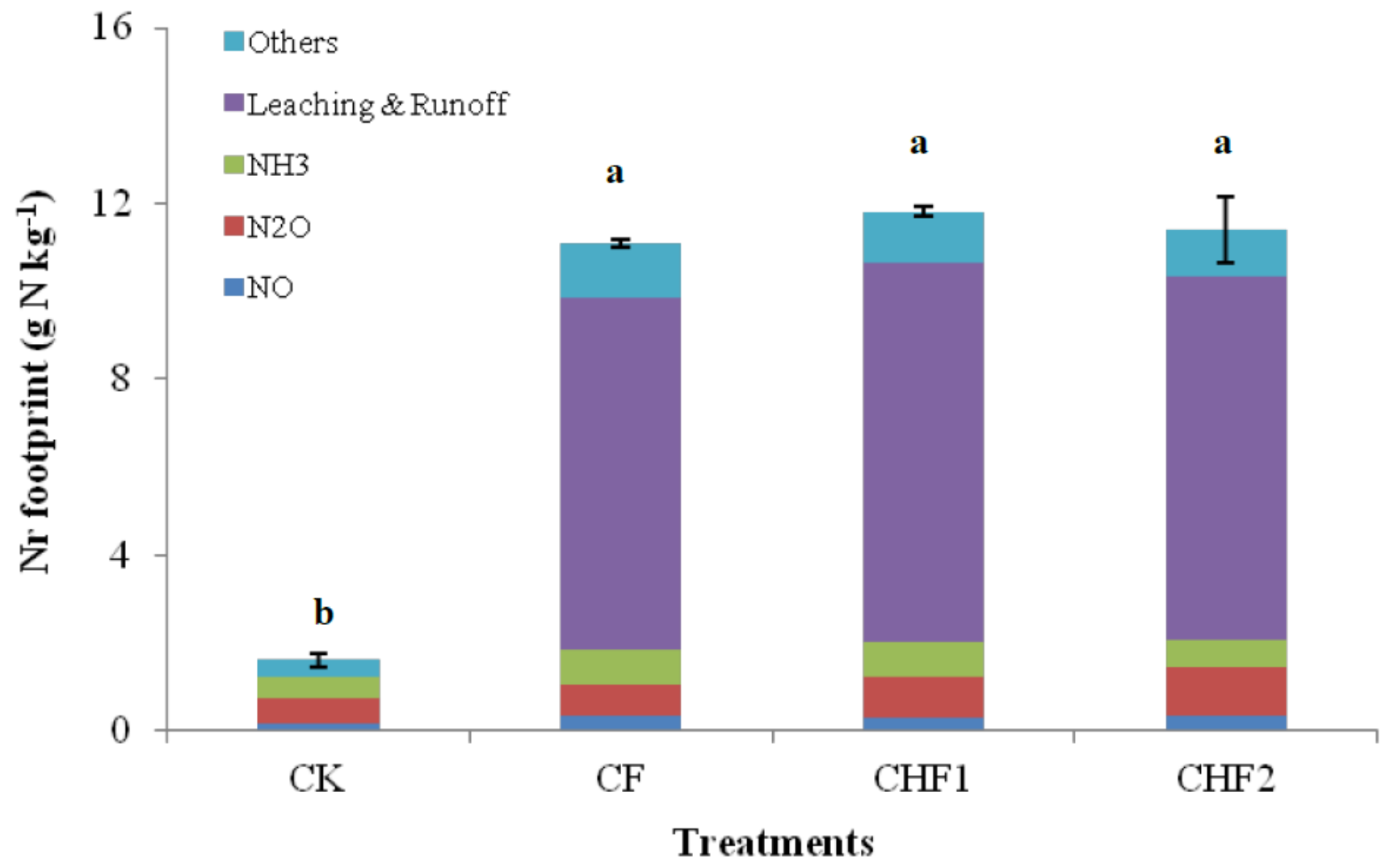

\section{Figure 3}

Contributions of different sources/activities to the $\mathrm{Nr}$ footprints of intensive vegetable production. $\mathrm{N}$ fertilizer refers to synthetic $\mathrm{N}$ fertilizer production, transportation and application; Others refers to the sum of other sources of GHG, such as the production of phosphorus, potassium and their transportation and application. The small letters in each sub figure indicate significant differences according to the Tukey's multiple range test ( $\mathrm{p}<0.05)$ among all the treatments. 


\section{Supplementary Files}

This is a list of supplementary files associated with this preprint. Click to download.

- Supplementaryinformation.docx 